Ege Ĕ̆itim Dergisi 2014 (15) 1: 300-317

\title{
Psikolojik Danışman Eğitiminde Mesleğe İlişkin Kişisel Eğilimler
}

Fidan KORKUT-OWEN*
$\begin{gathered}\text { Meliha TUZGÖL DOST } \\ \text { Dean W. OWEN }\end{gathered}$ Aslı BUGAY $^{* * * * *}$

\section{$\ddot{O} z$}

Psikolojik Danışma ve Rehberlik (PDR) eğitimi boyunca öğrencilerin gelişimi, daha çok alan bilgisi ve becerileri açısından değerlendirilmekte ve mesleğe ilişkin kişisel eğilimlerinde oluşan değişiklikler yeterince dikkate alınmamaktadır. Öte yandan son zamanlarda psikolojik danışman eğitimi boyunca öğrencilerin sadece akademik değil, profesyonel ve kişisel değişimlerinin de sürekli izlenmesi etik bir gereklilik olarak ifade edilmeye başlamıştır. Bu fikir Psikolojik Danışma ve İlgili Eğitim Kurumlarının Akreditasyonu Kurulu'nun (Council for Accreditation of Counseling and Related Educational ProgramsCACREP) 2009 standartlarıyla da pekiştirilmiştir. Amerika Birleşik Devletleri'nde (ABD) özellikle CACREP tarafından akredite edilen ya da akredite edilmek isteyen üniversitelerde PDR eğitimi almayı düşünen adayların seçiminde ve PDR eğitimi boyunca öğrencilerin değerlendirilmesinde mesleğe ilişkin kişisel eğilimler de dikkate alınmaya başlamıştır. Bu çalışmada alanyazında giderek daha fazla yer alan mesleğe ilişkin kişisel eğilim kavramının ne olduğu, PDR alanında neden önemli olduğu, ABD'deki bazı üniversitelerin bu kavramı programlarında öğrenci değerlendirmesinde nasıl ele aldıkları ve değerlendirme yolları üzerinde durulmuştur. Böylece Türkiye'de PDR eğitiminde de bu kavram üzerinde tartışmaya başlanması umulmaktadır.

Anahtar Sözcükler: mesleğe ilişkin kişisel eğilim, psikolojik danışman eğitimi, psikolojik danışman eğitiminde mesleğe ilişkin kişisel eğilimler.

\footnotetext{
* Prof. Dr., Hacettepe Üniversitesi, Emekli, Ankara, korkut@hacettepe.edu.tr

** Yrd. Doç. Dr., Hacettepe Üniversitesi, Ankara, mtuzgol@hacettepe.edu.tr

*** Yrd. Doç. Dr., TED Üniversitesi, Ankara, asli.bugay@tedu.edu.tr

**** Prof. Dr., Morehead State University, KY, ABD, Emekli, d.owen@moreheadstate.edu
} 
Ege Eğitim Dergisi 2014 (15) 1: 300-317

\title{
Profesional Dispositions in Counselor Education
}

\begin{abstract}
The assessment of student progress throughout counselor education training has been problematic in that earlier efforts have focused on content and skill mastery but did not attempt to assess belief or attitudinal change as the result of training. Within the field of counselor education there has emerged some discussions about assessments of the counselor candidates' dispositions besides their academic achievement. This assertion supported by the 2009 Standards of the Council for the Accreditation of Counseling and Related Educational Programs (CACREP), the national accrediting body for programs of counselor training (CACREP, 2009). These standards, to a large extent state that accredited programs are required to establish and maintain "a developmental, systematic assessment of each student's progress throughout the program, including consideration of the student's academic performance, professional development, and personal development". These standards describe an expectation that students in all education-related fields develop dispositions and that these behaviors and attitudes be observed and evaluated in educational settings. The aim of the study was to describe how dispositions in counselor education can be defined, how these dispositions can be developed or enriched, and how they can be assessed. The implication is that such assessment efforts would in some way contribute to effective and competent practitioners in future.
\end{abstract}

Keywords: professional disposition, counselor education, professional dispositions in counselor education. 



\section{Giriş}

Eğitim sürecinin en temel öğelerinden biri, öğrencilerin seçilmesi ve eğitimleri boyunca sürekli olarak izlenmeleri ve değerlendirilmeleridir. Öğrenci seçimi ve gelişiminin değerlendirilmesi sürecinde, daha çok bireyin eğitim verilen alandaki alan bilgisini öğrenmesine ilişkin başarısı ölçülmektedir. Türkiye'de tüm üniversitelere ve bölümlere öğrencilerin seçimi merkezi sınav aracılığı ile yapılmakta ve öğrenci alımında akademik başarı ölçüt olarak alınmaktadır. Psikolojik danışman eğitimi (counselor education) sürecinde de öğrenciler, eğitimleri boyunca sadece ödevler, sinavlar, projeler ve tezler aracılığı ile değerlendirilmektedir. Bu durum lisansüstü düzeydeki eğitim için de geçerlidir. Öte yandan ilgili alanyazında psikolojik danışma öğrencilerinin sadece akademik başarılarının değil, diğer özelliklerinin de dikkate alınması gerektiğine ilişkin bir eğilim vardır. Öyle ki son zamanlarda psikolojik danışman eğitimi boyunca öğrencilerin değişimlerinin sürekli izlenmesi etik bir gereklilik olarak görülmeye başlamıştır (Spurgeon, Gibbons ve Cochran, 2012). Bu fikir Psikolojik Danışma ve İlgili Eğitim Kurumlarının Akreditasyonu Kurulu'nun (Council for Accreditation of Counseling and Related Educational Programs - CACREP) 2009 standartlarıyla da pekiştirilmiştir. CACREP'in bu görüşü büyük oranda, Ulusal Öğretmen Eğitiminin Akreditasyonu Kurulu (National Council for Accreditation of Teacher Education NCATE, 2008) tarafından oluşturulan eğitim standartlarının tüm eğitim alanlarına uyarlanmasından etkilenmiştir. NCATE 1 Haziran 2013 tarihinde bir diğer akreditasyon kurumuyla birleşerek Eğitimcileri Hazırlama Akreditasyon Kurulu (The Council for the Accreditation of Educator Preparation - CAEP) adını almıştır (NCATE, 2014). Bu yazıda kurumun eski çalışmalarından sözedildiği için kurum NCATE olarak kullanılmaya devam edilmiştir.

CACREP, bu standartlarda, tüm eğitim alanlarındaki öğrencilerin mesleğe ilişkin kişisel eğilimlerinin (professional dispositions) geliştirilmesinin ve bu özelliklerin eğitim ortamında gözlenebilir ve değerlendirebilir olmasının beklendiğini ifade etmektedir. Bu tür değerlendirme çabalarının gelecekte daha etkili ve yeterli uygulamacıların yetiştirilmesine katkıda bulunma gibi bir doğurgusu vardır.

Mesleğe ilişkin kişisel eğilim kavramı, bu çalışmada professional dispositions kavramı yerine kullanılmaktadır. Bu kavrama Türkçe karşılık bulabilmek için Amerika Birleşik Devletleri'nde psikolojik danışma ve rehberlik (PDR) alanında yüksek lisans ya da doktorasını yapmış ya da doktora sonrası eğitiminin bir kısmını orada tamamlamış olan toplam yedi kişiden görüş alınmıştır. Gelen karşıllıklar arasında 
"profesyonel eğilim, kişisel yatkınlıklar, kişisel tavır, kişisel karakter özellikleri, kişisel eğilim, profesyonel duruş" yer almaktadır. Tanımlanması zor bir kavram olduğu konusunda hem fikir olunan kavrama verilen karşılıklar arasında en sık vurgulanan kavram olması nedeniyle bu çalışmada mesleğe ilişkin kişisel eğilimin kullanılmasına karar verilmiştir. Kavramı kısaltmak adına bu makalede mesleğe ilişkin kişisel eğilim kavramı kullanılsa da burada kastedilen aslında psikolojik danışma mesleğine ilişkin kişisel eğilimdir.

Psikolojik danışman eğitimi ile ilgili akreditasyon kurumu olan CACREP'e (2009) göre, psikolojik danışman eğitimi sonunda öğrencilerinin iyi bir psikolojik danışman olabilmeleri için alana ilişkin bilgi ve becerilerinin yanı sıra bazı mesleğe ilişkin kişisel eğilimlerinin gelişmesi ve zenginleşmesi beklenmektedir. NCATE ve CACREP'in giderek artan vurgulamalarına rağmen psikolojik danışmanların kazanmaları ya da geliştirmeleri beklenen bu özelliklerin neler olduğu ve nasıl değerlendirilebilecekleri konusunda yeterince çalışma bulunmamaktadır.

İlgili alanyazında da belirtildiği gibi kavramın tanımlanması, içeriği ve ölçülmesi konusunda görüş birliği olmasa da, ABD'deki tartışmalar gibi Türkiye'de de bu konuyu tartışmaya başlayabilmek için bazı çalışmaların yapılmasında fayda vardır. $\mathrm{Bu}$ yazıda mesleğe ilişkin kişisel eğilimler kavramının tartışılması amaçlanmıştır. Bu çalışma ile, Türkiye'de psikolojik danışman eğitimi süreci boyunca, psikolojik danışman adaylarının akademik yanlarının yanısıra mesleğe ilişkin kişisel eğilimleriyle ilgili tartışmaların ve yeni çalışmaların başlaması umulmaktadır. $\mathrm{Bu}$ tartışmaların PDR eğitiminde psikolojik danışman adaylarının hangi mesleğe ilişkin kişisel eğilimleri taşıması gerektiğini belirleyebilmek ve eğitim sürecinde mesleğe ilişkin kişisel eğilimlerini geliştirebilme yolları üzerine olması beklenmektedir.

\section{Mesleğe ilişkin kişisel eğilim kavramı}

Mesleğe ilişkin kişisel eğilim kavramının farklı tanımları vardır. Cudahy, Finnan, Jaruszewicz ve McCarty (2002) bu kavramı, içsel olarak sahip olunan ve davranışlar aracılığıyla dışardan görülebilen değerler, sorumluluk (söz verme, bağlı olma) ve etik kurallar olarak tanımlanmaktadır. Schultz ve Schultz, (1994) mesleki kişisel eğilimleri bireyi diğerlerinden ayıran ayırıcı özellikler olarak ele alırken (Akt., Pierce, 2010), Moore (2010) belli durumlarda, başkalarınca da gözlenebilecek şekilde belli biçimde davranma olasılığını artıran özellikler olarak ele almaktadır. 
Ege Eğitim Dergisi 2014 (15) 1: 300-317

Aslında mesleğe ilişkin kişisel eğilim kavramı, NCATE tarafından 2001 yılında oluşturulan performansa dayalı akreditasyon sisteminde yer almıştır. NCATE'nin (2010) kavramlar sözlüğünde yer alan mesleğe ilişkin kişisel eğilim, eğitimciler olarak öğrencilerle, ailelerle, meslektaşlarla ve toplumla etkileşim halindeyken sözel olan ve sözel olmayan davranışlarla gösterilen ilgili meslek kapsamındaki profesyonel tutumlar, değerler ve inançlar olarak tanımlanmaktadır. Buna göre, eğitimin tüm alanlarındaki öğrencilerin, mesleğe ilişkin kişisel eğilimleri ve eğitim ortamlarında gözlenebilen ve değerlendirilebilen tutum ve davranışları geliştirmeleri beklenmektedir. ABD'de NCATE, tüm eğitim fakültelerine bağl1 bölümleri akredite etme sürecinde, programlardan, öğrencilerinin mesleki kişisel eğilimlerini değerlendirmelerini istemektedir. Mesleki kişisel eğilim kavramı okul psikolojisi gibi psikolojik danışma ve rehberliğe yakın olan bazı mesleklerde de kullanılmaktadır. Ulusal Okul Psikologları Derneği (National Association of School Psychologists, 2009), profesyonel çalışma özellikleri kavramı altında öğrencilerin göstermesi beklenen özellikleri, bireysel ayrılıklara saygı, iletişim becerileri, etkili kişilerarası ilişkiler, etik sorumluluk, uyum gösterme, girişimci ve güvenilir olma olarak sıralamaktadır. Mesleğe ilişkin kişisel eğilimlerin öğretilebilir ve değiştirilebilir özellik göstermeleri (Knopp ve Smith, 2005) nedeniyle, psikolojik danışman eğitiminin öğrencilerin mesleğe ilişkin kişisel eğilimlerinde farklılık yaratması beklenmektedir.

CACREP (2009) son zamanlarda önerdiği standartlar temelinde, akredite edeceği programlardan bazı düzenlemeler istemektedir. Buna göre, her bir öğrencinin, program boyunca, akademik, profesyonel/mesleki ve kişisel olarak gelişimlerinin sistematik olarak değerlendirilmeleri gerekmektedir. Görüldüğü gibi, CACREP mesleğe ilişkin kişisel eğilim özelliklerinden söz etse de bunu henüz psikolojik danışman eğitiminin bir gerekliliği olarak ifade etmemektedir. CACREP'in, NCATE'den etkilenerek bu kavramı vurgulamaya başladığından daha önce söz edilmişti. Bu durumda gelecekte CACREP'in de NCATE gibi akredite edeceği psikolojik danışman programlarında öğrencilerin mesleğe ilişkin kişisel eğilim özelliklerinin değerlendirilmesini zorunlu hale getirmesi beklenmektedir. Psikolojik danışman yeterliliklerinin değerlendirilmesi konusunda bazı çalışmalar yapan Türk Psikolojik Danışma ve Rehberlik Derneği, PDR eğitim programlarının akredite edilmesi ile ilgili olarak Yükseköğretim Kurulu nezdinde bir girişimde bulunmuştur. Derneğin bu süreçte CACREP ile işbirliği de sürmektedir (Türk Psikolojik Danışma ve Rehberlik Derneği, 2011). Bu gelişmeler PDR öğrencilerinin 
mesleki kişisel eğilimlerinin değerlendirilmesi konusunun Türkiye'de de gündeme gelebileceğini göstermektedir.

\section{PDR'de mesleğe ilişkin kişisel eğilim}

Mesleğe ilişkin kişisel eğilim kavramı ile akademik olmayan özellikleri (Bucassa Beebe ve Toman, 2010; Corey, Corey ve Callahan, 1998) aynı anda kullananlar (Kuzey Carolina Central University, 2014) ya da eğitim sonunda kişisel gelişimlerinin izlenmesi (McKee, 2010) gibi nitelendirmeleri kullananlar da bulunmaktadır. PDR eğitiminin en temel amacının başarılı, yetkin ve etkili psikolojik danışmanlar yetiştirmek olduğu düşünüldüğünde, yetkin ve etkili psikolojik danışman özelliklerinin neler olduğu konusunun son 50 yıldır alanyazında tartışılmakta olması anlaşılır hale gelmektedir (Demos ve Zuwaylif, 1966; Pope ve Kline, 1999; Truax ve Carkhuff, 2007). Young'a (2009) göre, etkili ve yeterli psikolojik danışmanların özellikleri ile ilgili tartışmalar iki büyük grupta toplanabilmektedir. Yazara göre, ilk grupta psikolojik danışmanların profesyonel/mesleki eğitimleri boyunca öğrendikleri, insan gelişimi, bireysel ve grupla psikolojik danışma teknikleri, ölçme ve değerlendirme, psikolojik danışma kuramlarını bilme gibi psikolojik danışma alanındaki bilgi ve becerilere sahip olmaları ile ilgili nitelikleri ele alınmaktadır. Daha geniş olan diğer gruptaki nitelikler ise Truax ve Carkhuff (2007) ve Corey (2008) tarafından tanımlanan ve daha çok psikolojik özelliklere odaklanan türdendir. Bu temel psikolojik özelliklerin psikolojik danışmanlarda olması gerektiği pek çok araştırmacı tarafından kabul edilse de bu özelliklerin neler olduğu konusunda görüş birliği yoktur. Örneğin, Pierce (2010), Patterson ve Eisenberg (1983) ile Cormier ve Cormier (1985) tarafından yapılan ayrımları aktarmaktadır. Buna göre ilk yazarlar, etkili psikolojik danışman olabilmek için dört temel mesleki kişisel eğilimin varlığından söz etmektedir: İstikrar/ tutarlılık (stability), uyum (harmony), süreklilik (constancy) ve amaçlılık (purposefulness). İkinci yazar grubu ise etkili psikolojik danışmanların özelliklerini, bilişsel yetkinlik (intellectual competence), enerjik olma (energy), esneklik (flexibility), destekleyici olma (supportiveness), iyi niyetlilik (goodwill), öz farkındalık (self-awarenes) ve kültürel yaşantıların farkında olma (awareness of cultural experiences) biçiminde sıralamaktadırlar.

Corey (2008) istendik psikolojik danışman özelliklerini tanımlarken geleneksel psikolojik danışman eğitiminin içinde öğretilen eğitim materyalleriyle ilgili değil, daha çok tutum ve inançlara yönelik bazı özelliklerden söz etmektedir. İnsan doğasına yönelik olumlu bakış açısına sahip olmak (nature of human behavior); öz 
farkındalık; yardım etme ilişkisinde bireylerin gelişimine katkıda bulunmak (helping relationship); kişisel olarak bazı psikolojik danışma becerilerine sahip olmak (personal counseling skills) ve profesyonel psikolojik danışma sorumluluklarını/görevlerini yerine getirebilmek ve mesleki öz yeterlik duygusuna sahip olmak (technical self-efficacy). Halinski (2009), psikolojik danışmanların etkililiğine katkıda bulunan özelliklere ilişkin yaptığı alanyazın incelemesinde beş kişilik özelliğinin fazla vurgulandığını görmüştür. Bu kişisel özellikler, sıcak ve kabul edici olmak, empatik olmak, esnek olmak, öz farkındalık ve içtenlik olarak siralanmaktadir.

Mesleğe ilişkin kişisel eğilimlerin neler olabileceğini ortaya koymaya çalışan yeni bir araştırmada ise Spurgeon, Gibbons ve Cochran (2012), meslektaşlarıyla öğrencilerindeki ilerlemeleri tartışırken öğrencilerinin akademik olanlardan çok, öz farkındalık ve kişilerarası ilişkilerden kaynaklı sıkıntılar yaşadıklarını fark ettiklerini belirtmektedirler. Yazarlar başarılı olarak değerlendirilen öğrencilerin sadece akademik olarak başarılı olmakla kalmayıp aynı zamanda içtenlik, saygı, kültürel anlayış, diğer fikirlere açık olma ve güçlü bir çalışma etiğine sahip olma gibi kişisel özellikler gösterdiklerini de eklemektedirler. Spurgeon ve arkadaşları (2012), meslektaşlarıyla yaptıkları tartışmalarda programlarının kimliğini ve özünü tanımlayan beş mesleğe ilişkin kişisel eğilimin bağlılık (commitment -söz verme /sorumluluk), açıklık (openness), saygı (respect), dürüstlük (integrity) ve öz farkındalık olduğuna karar vermişlerdir.

Bu kavramın tartışılmasında, önce Rogers (1961) tarafından vurgulanan ve başka kuramcilar tarafından da (Örn., Duba, Paez ve Kindsvatter, 2010; Kelly, 2011; McKee, 2010) kabul edilen terapötik süreçte psikolojik danışmanların kişilik özelliklerinin beceri ve tekniklerden daha fazla etkisi olduğu düşüncesinin de payı bulunmaktadır. Bu bakış açısına göre kişi olarak psikolojik danışman, hizmetin sağlanmasında bir araç olarak görülmektedir. Farklı psikolojik danışmanlar aynı teknikleri kullansalar da bu tekniklerin kullanılışındaki araçlar aynı olmadığı için tekniğin kullanılışının da aynı olmayacağı üzerinde durulmaktadır. Bu görüşlerden yola çıkarak bazı psikolojik danışman eğitimi programları yüksek lisans düzeyinde öğrenci alımı sırasında adayların bazı akademik olmayan kişilik özelliklerini de göz önüne almaya başlamışlardır (Pierce, 2010). Redekop ve Wlazelek (2012), mesleki kişisel eğilimlerin öğrenci seçiminde dikkate alınması gerektiğine ilişkin bazı çalışmalar yapmışlarsa da psikolojik danışman adaylarının mesleğe ilişkin kişisel eğilimlerini gözönüne alarak öğrenci seçen üniversite sayısının fazla olduğu söylenemez. Orta Tennessee Devlet Üniversitesi (Middle Tennessee State 
University, 2014) ve Kuzey Carolina Merkez Üniversitesi (North Carolina Central University, 2014) bu konuya örnek olarak verilebilir. Bu üniversiteler, bazı formların doldurulması ve görüşmeler aracılığıyla yüksek lisans eğitimine başvuran adayları mesleğe ilişkin kişisel eğilim açısından da değerlendirmektedirler.

Mesleğe ilişkin kişisel eğilim, sadece psikolojik danışman eğitimi programına öğrenci seçiminin sırasında ele alınmamaktadır. Program boyunca öğrencilerin bu anlamda değişimlerinin izlenmesi de önemsenmektedir. Psikolojik danışman eğitimi sonunda öğrencilerin bilişsel olarak gerekli kuramsal bilgileri ve mesleki becerileri ne kadar öğrendikleri sınansa da, son zamanlarda psikolojik danışmaya ve kendilerine ilişkin görüşlerinin, tutumlarının, değerlerinin, daha açıkçası mesleki kişisel eğilimleri açısından ne kadar değiştikleri sorusuna da yanıt aranmaya başlanmıştır. Bu konuda North Carolina Central Üniversitesi (North Carolina Central University, 2014), Monmouth Üniversitesi (Monmouth University, 2014), New Mexico Highlands Universitesi (2011), Columbus State Üniversitesi (Columbus State University, 2013), Tennessee Üniversitesi Knoxville, (University of Tennessee-Knoxville, 2010), Radford Universitesi (Radford University, 2012), Wisconsin Üniversitesi-Stout (University of Wisconsin-Stout, 2012) gibi baz1 üniversiteler ise mezun olana dek PDR öğrencilerinde akademik özelliklerin dışında başka alanlarda da değişim olması gerektiğini vurgulayarak süreç içinde ve sonunda adayların mesleki kişisel eğilimlerini değerlendirmektedirler. Adı geçen üniversitelerin psikolojik danışma öğrencileri için hazırlanan el kitaplarında okulun politikalarından, yönetmeliklerden sözederken mesleğe ilişkin kişisel eğilimlerden de sözetmektedirler. Aşağıda birkaç üniversitenin öğrenci el kitabında mesleğe ilişkin kişisel eğilimlerin nasıl ele alındıklarıyla ilgili bazı bilgiler sunulmuştur.

Kuzey Carolina Central Üniversitesi'nde (North Carolina Central University, 2014) lisansüstü eğitime başvuranların mesleğe ilişkin kişisel eğilimleri / akademik olmayan özellikleri, başvuru görüşmesinde ve kabul edilmeleri halinde eğitim süresince değerlendirilmektedir. Görüşmeyi değerlendirmek için psikolojik danışman eğitimcileri her aday için mesleğe ilişkin kişisel eğilimleri değerlendirme formu doldurular. Ancak bazı durumlarda mesleğe ilişkin kişisel eğilimler kabul süreci kesinleştikten sonra görülür. O nedenle psikolojik danışman eğitimcileri her öğrenciyle ilgili düzenli olarak gözlemler ve değerlendirmeler yaparlar. Öğrenciyle ilgili herhangi bir kaygı olması halinde iyileştirme ya da yeniden değerlendirme planları yapılır. Derslerin tamamlandığı ve öğrencinin uygulama derslerine 
yöneldiği zaman ilk kiritik değerlendirme yapılır ve bu, program ortası değerlendirme diye adlandırılır. Bu değerlendirme bir portfolyo hazırlamaya dayalıdır. $\mathrm{Bu}$ portfolyoda her öğrencinin yeterliliği ve profesyonelliği değerlendirilir. $\mathrm{Bu}$ değerlendirme öğretim üyelerinin öğrencinin alan süpervizyonuna başlamaya hazır oluşunu onaylamalarına yardımcı olur. Öğrenci hazır değilse onunla iyileştirme planı yapılır, gerekirse yeni kariyer yönü çizmesi için öğrenciye yardımcı olunur. Öğrenci el kitabında açı olarak öğrencinin dönemin belli bir noktasında etik olmayan, mesleğe uymayan bir davranışı göstermesi ya da iyileşirme planındaki gereklilikleri yapmaması halinde, programdan kaydının silinebileceğinden de söz edilerek bu özelliklere verilen önem vurgulanmaktadır.

Monmouth Üniversitesi'nde (2014) de üniversitenin politikalarına uygun olarak, tüm öğrencilerin ilerlemeleri ve mesleğe ilişkin kişisel eğilimleri gözden geçirilir ve bir form kullanarak değerlendirilir. Öğrenciler aylık dönemlerde değerlendirilirler ve sorun olması halinde işbirliği ile bir hareket planı yapılır. Öğrencilerden sadece üniversitede değil uygulama ve staj yapmaya gittikleri yerlerde, danışanlarıyla, sınıf arkadaşlarıyla, öğretim üyeleriyle ve diğer çalışanlarla etkileşim halindeyken mesleğe ilişkin kişisel eğilimler göstermeleri beklenmektedir. Bunlar içtenlik, dürüstlük, saygı, koşulsuz olumlu kabul ve empati olarak özetlenmektedir. Bu el kitabında da uygunsuz, olgun olmayan, rahatsızlık verici, mesleğe uygun olmayan, saldırgan davranışlar gösterenlerin üniversiteyle ilişkilerinin kesilebileceği notu yer almaktadir.

New Mexico Highlands Üniversitesi'nin (2011) PDR öğrencileri için hazırladıkları el kitabında yer alan programın felsefesinde, psikolojik danışma öğrencilerinden sadece akademik alanda değil mesleğe ilişkin kişisel eğilimlerde de gelişim beklendiğinden sözedilmektedir. Bu eğilimler ise empati, içtenlik, koşulsuz kabul, açı fikirli olma, bireyi hem bireysel hem de sistemik çerçevede görebilme, bireylerin psikolojik iyilik hallerini artırmaya istekli olma, yetkinlik, farklılıklara duyarlık olarak sıralanmaktadır. Öğrenciler program boyunca birkaç kez bu özellikler açısından değerlendirilmektedirler.

Wisconcin Universitesi'nin Stout kampüsünde de (Wisconcin University University-Stout, 2012) öğrencilerin mesleğe ilişkin kişisel eğilimleri bir formla düzenli aralıklarla değerlendirilmektedir. Bu formda öğrencilerin devam, hazır gelme, sürekli öğrenme, olumlu ruh hali, olup bitenin farkında olmak, düşünceli olma, işbirliği ile çalışma gibi bir dizi mesleğe ilişkin kişisel eğilimleri dörtlü 
dereceleme (doyurucu değil-1, en alt düzeyde doyurucu-2, doyurucu-3 ve yeterli-4) üzerinden değerlendirilmektedir. Kabul edilen en düşük dereceleme üç olduğu için öğrenciye herhangi bir alanda üçten daha az değerlendirme verilmişse, öğrencinin o alanı iyileştirmesine yönelik yazılı bir plan hazırlanmaktadır. Yeni öğrencilere oryantasyon yapılırken mesleğe ilişkin kişisel eğilimlerle ilgili derinlemesine bir tanıtım yapılmakta, ders veren psikolojik danışman eğitimcileri ders içinde ve dışında öğrencilere bu konuda geribildirim vermektedir. Bu etmenlerin, başarılı bir programın kişilerarası ve mesleki nitelikleri konusunda öğrencilerin farkındalığını artırmaya katkıda bulunduğu düşünülmektedir.

\section{Mesleğe ilişkin kişisel eğilimlerin değerlendirilmesi}

Aslında yıllar önce Johnson, Shertzer, Linden ve Stone (1967) öğrencilerin bilişsel ve akademik olmayan özelliklerinin psikolojik danışma ilişkisinin etkililiğinde önemli olduğu konusunda psikolojik danışman eğitimcilerinin hemfikir olduğunu belirterek adayların bu anlamda değerlendirilmesi gerektiğini vurgulamışlardır. $\mathrm{O}$ anlamda CACREP'in standartları ve yukarıda sözedilen üniversitelerdeki uygulamaları, öteden beri önerilen fikirlerin uygulanmaya başlandığını göstermektedir. Verilen örneklerde mesleğe ilişkin kişisel eğilimlerin değerlendirilmesinin daha çok formlarla yapıldığı görülmektedir. Oysa başka yolların da olduğunu gösteren çalışmalar bulunmaktadır.

Mesleğe ilişkin kişisel eğilimlerin ne olduğu konusunda görüş birliği olmadığı gibi değerlendirilebileceği ya da değerlendirilmesi gerektiği ya da nasıl değerlendirileceği konusunda da bir görüş birliği yoktur. Singh ve Stoloff (2008), mesleki kişisel eğilimlerin tanımlanmasının ve ölçülmesinin zor olduğunu belirtmekle beraber bir değerlendirmenin yapılması gereğinden söz etmektedirler. Stoddard, Braun, Dukes ve Koorland (2007) eğitim alanında mesleğe ilişkin kişisel eğilimlerin nasıl ölçülebileceğine ilişkin çalışmalarında bir dizi yoldan söz etmektedirler. $\mathrm{Bu}$ yollardan bazılarını, bireylere mesleğe ilişkin kişisel eğilim kontrol listesi vermek, bireylerin kendileriyle ilgili notlar (günlükler) tutmalarını sağlamak, görüşmeler yapmak, portfolyo hazırlmalarını istemek, klinik değerlendirmeler yapmak olarak sıralamaktadırlar. Onlara göre çok sayıdaki teknik aracılığ 1 ile öğrencilerin mesleğe ilişkin kişisel eğilimlerinin gelişimi ve bu kavrama karşı farkındalıkları artırılabilir.

Barrio-Minton ve Gibson (2012), psikolojik danışman eğitimcilerinin öğrencilerin öğrenme sonuçlarını değerlendirmeleriyle (student learning outcome) ilgili bir 
çalışma yapmışlardır. Çalışmada öğrencilerin mesleğe ilişkin kişisel eğilimlerine belli bir sayısal ağırlık verilerek performans göstergeleri olarak ele alma yoluyla derslere ve portfolyolara yedirilmiş ölçümler geliştirilmeye başladıklarından sözetmektedirler.

\section{Mesleğe ilişkin kişisel eğilimleri ölçmeye yönelik ölçek çalışmaları}

Alanyazında psikolojik danışman adaylarının mesleğe ilişkin kişisel eğilimlerini ölçmeye yönelik ölçek çalışmaları yenilerde başlamış görünmektedir. Psikolojik danışma alanına ilişkin olarak rastlanan ölçeklerden biri olan Psikolojik Danışman Eğitiminde Mesleki Kişisel Eğilimleri Değerlendirme (Dispositional Assessment in Counselor Education) adlı ölçek Owen (2009) tarafından NCATE'in psikolojik danışman eğitiminde öğrencilerde fark yaratıldığının belgelenmesini istenmesi üzerine geliştirilmiştir. Ölçek Corey'in (2008) yukarıda sözü edilen etkili bir psikolojik danışmanın özellikleriyle ilgili görüşlerinden yola çıkılarak hazırlanmıştır. Bu özellikler; insan doğasına yönelik olumlu bakış açısına sahip olma; öz farkındalığa sahibi olma; yardım etme ilişkisinde bireylerin gelişimine katkıda bulunma; mesleki kişisel olarak bazı psikolojik danışma becerilerine ve bu becerileri kullanabileceğine ilişkin mesleki öz yeterlik duygusuna sahip olma olarak beş grupta ele alınmaktadır. Bu beş boyuta göre hazırlanmış olan toplam 30 maddelik Psikolojik Danışman Eğitiminde Mesleğe İlişkin Kişisel Eğilimleri Değerlendirme Ölçeği için yüzeysel geçerlik çalışması yapılmış ve ölçekle ilgili dört psikolojik danışman eğitimcisinden geribildirim alınmıştır. Ölçek psikolojik danışma alanında ve eğitim bilimleri alanlarında yüksek lisans eğitimi gören öğrenciye uygulanmış ve her iki grup arasında yapılan karşılaştırmada toplam puanlar açısından anlamlı fark bulunması ölçeğin geçerliğine bir kanıt olarak düşünülmüştür.

Williams, Williams, Kautzman-East, Stanley, Evans ve Miller (2014), yakın zamanda sundukları bir bildiride Mesleğe İlişkin Kişisel Eğilim Ölçeği-Psikolojik Danışma Öğrencileri Versiyonu (Professional Dispositions Scale-Counseling Student Version) adlı bir ölçek geliştirdiklerini belirtmişlerdir. Williams ve arkadaşları sunularında, ölçeği CACREP'in PDR programlarını akredite etme standartlarında yer alan sekiz çekirdek alana dayalı olarak geliştirdiklerini dile getirmektedirler. Sözü geçen ölçeğin, 59 tanesi mesleğe ilişkin kişisel eğilimlerle ilgili, kalanı demografik bilgilerle ilgili olan toplam 74 maddeden oluştuğu rapor edilmiştir. Bu iki çalışmada mesleğe ilişkin kişisel eğilimleri, formlar ve görüşmeler aracıllğı ile 
ölçmenin yanı sıra, psikometrik özellikleri olan ölçeklerle değerlendirme çabalarının olduğu görülmektedir.

\section{Türkiye'deki ilgili yayınlar}

Türkiye'de mesleğe ilişkin kişisel eğilimler kavramı yerine, kişilik özellikleri konusunda bazı yayınlara rastlanmıştır. Örneğin, Kepçeoğlu (1999) rehber öğretmenlerin eğitimle kazandıkları bilgi ve becerilerin yanı sıra bazı kişilik özelliklerine sahip olması beklendiğinden söz etmektedir. Belirttiği bu özelliklerden bazıları, cesaretlendirici olma, eleştirel olma, destekleyici olma, yakınlık, kendini açabilme, problem çözebilme, açı görüşlülük, empati kurabilme, ince düşünme, aktif dinleyebilme, sorumluluk alabilme, güvenilir olma, aktif olma, güç ve kontrol becerisine sahip olma, uyumlu olma, dengeli olma ve sabırlılıtır.

Mesleğe ilişkin kişisel eğilim kavramına yakın olan kavramlarla yapılmış bazı araştırmalar da vardır. Örneğin, psikolojik danışmanların (rehber öğretmenlerin) kişilik özellikleri (Muslu-Köseoğlu, 1994), ideal psikolojik danışman özellikleri (Çiftci 1991) ile etkili psikolojik danışman özelliklerini değerlendirmeye (İkiz ve Totan, 2011) ve psikolojik danışmanların öz yeterliğini ölçmeye yönelik (Demirel, 2012) çalışmalar bunlardan bazılarıdır.

Söz edilen araştırmalarda elde edilen bulgular kısaca şu şekilde özetlenebilir. Muslu-Köseoğlu (1994), okullarda çalışan rehber öğretmenlerin (psikolojik danışmanların) başatlık, düzen, sebat, duyguları anlama, yakınlık, gösteriş, ideal benlik, yaratıcı kişilik ve asgari liderlik gibi kişilik özelliklerine sahip olduklarını belirlemiştir. Çiftci (1991) tarafından yapılan araştırmada, psikolojik danışmanlar ve ilgili bölümlerdeki öğretim üyelerinin görüşlerine dayanarak psikolojik danışmanların ideal özellikleri çalışılmıştır. Çalışma sonucunda belirlenen 126 sıfattan bazıları şunlardır: Anlayışlı, dile hakim, duyarlı, empatik, esnek, güvenilir, iletişim kurabilen, kendisiyle barışık, mesleğini seven, önyargısız, sabırlı, sır tutan ve yargılamayan. İkiz ve Totan (2011) tarafından yapılan çalışmada, etkili yardım eden özelliklerinden yola çıkılarak genel olarak bir psikolojik danışmanın sahip olması gereken bilişsel yeterlik, enerji, esneklik, destek, iyi niyet ve öz-farkındalık özelliklerini belirlemeye yönelik bir ölçek geliştirilmiştir. Çalışmada ölçeğin altı boyutu olduğu sonucuna varılmıştır. Demirel (2012) tarafından yapılan çalışmada ise psikolojik danışmanların öz yetkinliklerini ölçmek amacıyla bir ölçek geliştirilmiştir. Ölçeğin etkili hizmet sunma ve bunu danışana iletme olmak üzere iki boyutu bulunmaktadır. 
Görüldüğü gibi, Türkiye'de benzeri kavramlarla yapılan çalışmalar bulunsa da CACREP'in önerdiği haliyle, psikolojik danışman adaylarının mesleğe yönelik kişisel eğilimlerine yönelik bir çalışmaya rastlanmamıştır. Çalışmalarda, psikolojik danışman unvanı almış kişilerin etkili ve öz yetkinliği olan psikolojik danışman olmaları için sahip olmaları gerekli özellikleri üzerinde durulmuştur. Çalışmalarda PDR eğitimi boyunca psikolojik danışman adaylarının bu özelliklerinin neler olabileceği, nasıl geliştirilebilecekleri, bu özellikler açısından nasıl değerlendirilebilecekleri ve bu kavramın psikolojik danısman eğitiminde nasıl kullanılabileceği konusu üzerinde durulmamıştır. Öğrenci seçiminde ya da öğrencinin süreç boyunca değerlendirilmesinde mesleğe ilişkin kişisel eğilim kavramından nasıl yararlanılabileceğine ilişkin bir tartışma da bulunmamaktadır. Bunun nedenlerinden birisi Türkiye' de PDR eğitiminin lisans düzeyinde başlaması ve lisans öğrencilerinin seçiminin merkezi üniversite sınavı ile yapılmasıdır. Lisansüstü düzeyde de merkezi sinavlardan alınan (Akademik Personel ve Lisansüstü Eğitimi Giriş Sınavı, Yabancı Dil Sınavı gibi) puanlar önemli olmakta, ayrıca üniversitelere bağlı olarak adaylarla ayrıca görüşme yapmak gibi ek değerlendirmeler de kullanılmaktadır. Bu nedenle, Türkiye'de lisans düzeyinde olmasa da lisansüstü eğitimde öğrenci seçiminde mesleğe ilişkin kişisel eğilimler dikkate alınabilir. Alanyazına göre, her iki düzeyde de öğrencilerin mesleğe ilişkin kişisel eğilimleri açısından gelişim ve değişimlerinin incelenmesi konusunda çalışmaların yapılması anlamlı olabilir. Türkiye'de PDR alanındaki lisans öğrencilerinin fazla olduğu dikkate alındığında onlara yönelik çalışmalara daha fazla gereksinim vardır. Örneğin öncelikle psikolojik danışma öğrencilerden beklenen mesleki kişisel eğilimlerinin neler olduğuna ilişkin bir araştırma yapılabilir. Uygulamalı dersler aracılığı ile öğrencilerin onlardan beklenen mesleki kişisel eğilimlere ne oranda sahip olduklarının belirlenmesi çok önemlidir. Bu eğilimleri daha da geliştirmek için ne tür müdahalelerin yapılabileceği, geliştirme çalışmalarına rağmen alanyazında yer alan içtenlik, saygı, kültürel anlayış, diğer fikirlere açı olma gibi özelliklere yeterince sahip olmayanlara karşı ne tür etik süreçlerin işletilebileceği de tartışmaya değer konulardandır.

\section{Sonuç ve Öneriler}

Bu çalışmada, ülkemizde henüz yeterince tanınmayan bir kavram olan mesleğe ilişkin kişisel eğilimin temel özellikleri ve ilgili araştırmalar tanıtılmaya çalışılmıştır. Mesleğe ilişkin kişisel eğilim kavramı psikolojik danışma alanında çalışan uzmanların uygulamalarının niteliğine ilişkin olası güçlü ilişkisi nedeniyle araştırmacıların ve eğitimcilerin son yıllarda artan bir şekilde ilgisini çekmekte ve 
bu nedenle bu kavramın işevuruk tanımı gittikçe önem kazanmaktadır. Psikolojik danışma alanının doğası gereği psikolojik danışman eğitiminin öğrencilerin mesleğe ilişkin kişisel eğilimlerinde farklılık yaratması beklenmektedir. Bu nedenle ilgili alanyazında psikolojik danışman eğitiminde mesleki kişisel eğilimi farklı şekillerde ölçmeyi amaçlayan ölçme değerlendirme teknikleri görülmektedir. Ancak henüz ülkemizde bu kavramla ilgili araştırmalar ve tartışmalar bulunmamaktadir.

Bu kavram tutum ve inançlara bağlı olarak gelişen psikolojik süreçlerden oluştuğu için kültüre özgü değerlerden etkilenmeye açık görünmektedir. Buna göre, kavramin kültüre özgü olarak farklılaşması beklenmekte ve bu durum yerel/kültüre özgü çalışmaların yapılmasının gerekliliğini ortaya koymaktadır. Ülkemizde yapılacak olan çalışmalarda, psikolojik danışman eğitimcilerinin bu konudaki görüşlerinin alınması, gelecekteki araştırmalar için zemin oluşturabilir. Daha açık bir deyişle, psikolojik danışman eğitimcilerinin, psikolojik danışman adaylarının sahip olmaları ve eğitim boyunca geliştirmeleri beklenen mesleğe ilişkin kişisel eğilimlerin neler olduğu, bunların nasıl geliştirilebileceği ve nasıl değerlendirilebileceğine ilişkin görüşlerinin alınması anlamlı görünmektedir. Böylece bu kavramın ülkemizde tartışılmaya başlaması ve buna göre eğitim programlarında gerekli düzenlemelerin yapılabilmesi için zemin oluşturulması sağlanabilir. PDR programlarının yeniden gözden geçirilmesi ve uygulanan programların etkililiğinin değerlendirilmesinde mesleğe ilişkin kişisel eğilimin de dikkate alınması gerekmektedir. Bu bağlamda, PDR programlarının etkililiğini ve öğrencilerin mesleğe ilişkin kişisel eğilimlerindeki değişimini değerlendirebilmek için standardizasyonu yapılmış ölçme araçlarına ihtiyaç vardır. Bu amaçla psikolojik danışman adaylarının mesleğe ilişkin kişisel eğilimleri konusunda Türkiye'ye özgü bir ölçek geliştirme çalışmasının yapılması anlamlı olabilir. Bu çalışmanın yazarları, PDR eğitimcilerinin görüşleri ışığında bir ölçek geliştirme çalışması içindedirler. Sonuç olarak, bu kavram hem araştırmaçlar hem PDR eğitimcileri hem de öğrenciler açısından önemli görülmekte ve bu çalışmanın bu alandaki çalışmaları hızlandırması umulmaktadır. 


\section{Kaynakça}

Barrio Minton, C.A. ve Gibson, D. M. (2012). Evaluating student learning outcomes in counselor education: recommendations and process considerations. Counseling Outcome Research and Evaluation, 3(2), 73-91.

Busacca, L.A., Beebe, R.S. ve Toman, S.M. (2010). Life and work values of counselor trainees: A national survey. The Career Development Quarterly, 59(1), 2-18.

Council for Accreditation of Counseling and Related Educational Programs (2009). Council for accreditation of counseling and related educational programs, 2009 standards. $\quad$ http://www.cacrep.org/wp-content/uploads/2013/12/2009Standards.pdf adresinden 29.07.2013 tarihinde alınmıştır.

Columbus State University (2013). Counseling student disposition rating form. http://cfl.columbusstate.edu/resources.php adresinden 12.08.2013 tarihinde alınmıştır.

Corey, G. (2008). Theory and practice of counseling and psychotherapy, (8 $8^{\text {th }}$ Ed). Thomson Brooks/Cole.

Corey, G., Corey, M. S. ve Callahan, P. (1998). Issues and ethics in the helping professions. (3rd ed.). Pacific Grove: Brooks/Cole Publishing Company.

Cudahy, D., Finnan, C., Jaruszewicz, C. ve McCarty, B. (2002). Seeing dispositions: Translating our shared values into observable behavior. Paper presented at the First Annual Symposium on Educator Dispositions, Richmond, Kentucky.

Çiftci, N. (1991). Danışmanların ideal özellikleri. Yayınlanmamış yüksek lisans tezi. Marmara Üniversitesi, Sosyal Bilimler Enstitüsü, İstanbul.

Demirel, Y. (2013). Psikolojik danışman öz yetkinlik ölçeğinin hazırlanması. Yayınlanmamış yüksek lisans tezi. Hacettepe Üniversitesi, Sosyal Bilimler Enstitüsü, Ankara.

Demos, G. ve Zuwaylif, F. (1966). Characteristics of effective counselors. Counselor Education and Supervision, 5(3), 163-165.

Duba, J. D., Paez, S. B. ve Kindsvatter, A. (2010). Criteria of nonacademic characteristics used to evaluate and retain community counseling students. Journal of Counseling and Development, 88(2), 5-12.

Halinski, K. H. (2009). Predicting beginning master's level counselor effectiveness from personal characteristics and admissions data: An exploratory study. Unpublished doctoral dissertation. University of North Texas, Texas. 
İkiz E. ve Totan, T. (2011). Etkili psikolojik danışman özelliklerini değerlendirme ölçeğini (EPÖDÖ) geliştirme çalışması, XI. PDR Kongresinde sunulan sözlü bildiri. 2-5 Ekim 2011, Selçuk, İzmir.

Johnson, D., Shertzer, B., Linden, J. E. ve Stone, S. C. (1967). The relationship of counselor candidate characteristics and counselor effectiveness. Counselor Education and Supervision, 6, 397-304.

Kelly, V. A. (2011). Assessing individual student progress: Meeting multiple accreditation standards and professional gatekeeping responsibilities. Journal of Counselor Preparation and Supervision, 3(2), 111-122.

Kepçeoğlu, M. (1999). Psikolojik danışma ve rehberlik. İstanbul: Alkım.

Knopp, T. Y. ve Smith, R. L. (2005). A brief historical context for dispositions in teacher education. In R. L. Smith, D. Skarbek, ve J. R. Hurst. (Eds.) The passion of teaching:Dispositions in the schools. (pp.1-14). Lanham, Maryland: Scarecrow Education. http://chapters.scarecrowpress.com/15/788/1578862035ch1.pdf adresinden 10.09.2012 tarihinde alınmıştır.

McKee, M. (2010). Personal development: A part of the counselor education experience, The Association for Counselor Education \& Supervision, S P E C T R U M, 7(3). 11-14

Middle Tennessee State University (2014). Master of education in professional counseling. http://www.mtsu.edu/edu_leadership/professional_counseling/docs/Hand book.4.12.13.pdf adresinden 12.01.2014 tarihinde alınmıştır.

Monmouth University (2014). Department of educational leadership, school counseling, and special education. School counseling, student affairs $\mathcal{E}$ college counseling programs manualhttp://www.monmouth.edu/uploadedFiles/Content/School_of_Educa tion/programs/graduate/edcounseling/COUNSELING\%20PROGRAM\%20H ANDBOOK\% 202013\%202014.pdf adresinden 09.04.2014 tarihinde alınmıştır.

Moore, J. (2010). What do mental terms mean? The Psychological Record, 60, 699-714.

Muslu-Köseoğlu, S. (1994). Psikolojik danışmanlarm empatik becerilerinin ve kişilik özelliklerinin incelenmesi, Yayınlanmamış Yüksek Lisans Tezi, Marmara Üniversitesi, Sosyal Bilimler Enstitüsü, İstanbul.

National Association of School Psychologists. (2009). Standards for training and field placement programs in school psychology. http://www.nasponline.org/standards/FinalStandards.pdf_adresinden 23.02.2012 tarihinde alınmıştır.

National Council for Accreditation of Teacher Education (2008). Professional standards accreditation of teacher preparation institutions 
Ege Eğitim Dergisi 2014 (15) 1: 300-317

http://www.ncate.org/Portals/0/documents/Standards/NCATE\%20Standa $\underline{\text { rds } \% 202008 . p d f}$

adresinden 01.04. 2012 tarihinde alınmıştır.

National Council for Accreditation of Teacher Education (2010). NCATE glossary. http:/ / www.ncate.org/Standards/NCATEUnitStandards/NCATEGlossary/t abid/477/Default.aspx\#P adresinden 01.04. 2012 tarihinde alınmıştır.

National Council for Accreditation of Teacher Education (2014). Council for the accreditation of educator preparation. http://www.ncate.org/ adresinden 12.01.2014 tarihinde alınmıştır.

New Mexico Highlands University (2011). Counseling program student handbook: Professional counseling school counseling rehabilitation counseling. http:/ /its.nmhu.edu/IntranetUploads/002002-Handbook_-_C129201011657.pdf adresinden 18.01.2014 tarihinde alınmıştır

North Carolina Central University (2014). School of education counselor education student handbook http://www.nccu.edu/formsdocs/proxy.cfm?file_id=2453 adresinden 23.02.2014 tarihinde alınmıştır.

Owen, D. W. (2009). Dispositional assessment in counselor education Instrument development and initial data collection. Unpublished report, Morehead State University, Kentucky.

Pierce, L. M. (2010). An exploration of the relationships among wellness, spirituality, and personal dispositions of practicing professional counselors. http://trace.tennessee.edu.utk_graddiss/738 adresinden 17.06.2013 tarihinde alınmıştır.

Pope, V. ve Kline,W. (1999). The personal characteristics of effective counselors: What 10 experts think. Psychological Reports, 84(5), 1339-1344.

Redekop, F. ve Wlazelek, B. (2012). Counselor dispositions: An added dimension for admissions decisions. VISTAS Online, Article 17. http://counselingoutfitters.com/vistas/vistas_2012_TOC-section_01.htm adresinden 17.01.2013 tarihinde alınmıştır.

Rogers, C. (1961). On becoming a person. Boston: Houghton Mifflin.

Singh, D. ve Stoloff, D. (2008). Assessment of teacher dispositions. College Student Journal, 42(4), 1169-1180.

Spurgeon, S., Gibbons, M. ve Cochran, J. (2012). Creating personal dispositions for a professional counseling program. Counseling and Values, 57(4), 96-108. 
Psikolojik Danışman Eğitiminde Mesleğe İlişkin Kişisel Eğilimler

Stoddard, K., Braun, B., Dukes, L. ve Koorland, M. A. (2007). Building professional dispositions in pre-service special educators: Assessment and instructional tactics. Journal of University Teaching and Learning Practice, 4, 28-39.

Truax, C. B. ve Carkhuff, R. (2007). Toward effective counseling and psychotherapy: Training and practice. Chicago: Aldine.

Türk Psikolojik Danışma ve Rehberlik Derneği, (2011). Türkiye'de psikolojik danışma ve rehberlik.

http://pdr.org.tr/upload/icerik/haberler/saglik\%20meslek\%20yasasi.pdf adresinden 21.10.2013 tarihinde alınmıştır.

University of Tennessee (2010). School counseling - Master of science - General requirements., http://web.utk.edu/ edpsych/school_counseling/ms_requirements.html adresinden 12.01.2014 tarihinde alınmıştır.

University of Wisconsin-Stout (2012). M.S. in school counseling assessment in the major report 2011-12. http://www.uwstout.edu/soe/assess/upload/10-122012-SCOUN-2011-12-Program-AIM-Report.pdf adresinden 18.01.2014 tarihinde alınmıştır.

Williams, J. L., Williams, D. D., Kautzman-East, M., Stanley A. L., Evans V. J. ve Miller, K. L. (2014). Assessing student dispositions in counselor training programs: Implications for supervision, program policy, and legal risk management.Presented at the Ohio Association for Counselor Education and Supervision Winter Meeting January 31, 2014 Columbus, OH. http://oaces.org/wpcontent/uploads/2013/07/MILLER-1-24-14-Assessing-StudentDispositions.pdf adresinden 25.03.2014 tarihinde alınmıştır.

Young, M. E. (2009). Learning the art of helping: Building blocks and techniques (4th ed.).Upper Saddle River, NJ: Pearson. 